\title{
Personal body ornamentation on the Southern Iberian Meseta: An archaeomineralogical study
}

\author{
Carlos P. Odriozola ${ }^{\text {a,* }}$, Luis Benítez de Lugo Enrich ${ }^{\text {b,c }}$, Rodrigo Villalobos García ${ }^{\text {c }}$, José M. Martínez-Blanes ${ }^{\text {d }}$, \\ Miguel A. Avilés ${ }^{\mathrm{e}}$, Norberto Palomares Zumajo ${ }^{\mathrm{f}}$, María Benito Sánchez ${ }^{\mathrm{g}}$, \\ Carlos Barrio Aldea ${ }^{\text {}}$, Domingo C. Salazar-García ${ }^{\mathrm{i}, \mathrm{j}}$
}

a Dpto. de Prehistoria y Arqueología, Universidad de Sevilla, Spain

${ }^{\mathrm{b}}$ Dpto. de Prehistoria y Arqueología, Universidad Autónoma de Madrid, Spain

c Dpto. de Prehistoria y Arqueología, Centro asociado UNED-Ciudad Real, Universidad Nacional de Educación a Distancia, Spain

d Dpto. de Prehistoria, Arqueología, Antropología Social y Ciencias y Técnicas Historiográficas, Universidad de Valladolid, Spain

e Instituto de Ciencia de Materiales de Sevilla, Centro mixto Universidad de Sevilla-CSIC, Spain

${ }^{\mathrm{f}}$ Anthropos, s.l., Spain

g Laboratorio de Antropología Forense, Universidad Complutense de Madrid, Spain

${ }^{\text {h }}$ Archaeologist

${ }^{i}$ Department of Archaeology, University of Capetown, South Africa

j Departament de Prehistòria i Arqueologia, Universitat de València, Spain

\section{A R T I C L E I N F O}

Article history:

Received 22 June 2015

Received in revised form 30 October 2015

Accepted 14 November 2015

Available online 5 December 2015

\begin{abstract}
A B S T R A C T
Beads and pendants from the Castillejo del Bonete (Terrinches, Ciudad Real) and Cerro Ortega (Villanueva de la Fuente, Ciudad Real) burials were analysed using XRD, micro-Raman and XRF in order to contribute to the current distribution map of green bead body ornament pieces on the Iberian Peninsula which, so far, remain undetailed for many regions. XRD, micro-Raman and XRF analyses showed that most of the beads from Castillejo del Bonete (Late 3rd millennium cal. BC) were made from variscite or green phyllosilicates, while Cerro Ortega's (Late 4th millennium cal. BC) beads were made out of fossil wood or Clinochlore. Significantly enough, while XRD pointed to variscite as the main crystallo-graphic phase, the elemental composition did not match any elemental compositions of known and characterised sources, thus suggesting an unknown south-eastern source or an extra-peninsular origin of these ornamental pieces.
\end{abstract}

(C) 2015 Elsevier Ltd. All rights reserved.

\section{Introduction}

Green body ornaments have been recovered from different Late Prehistory sites around the Iberian Peninsula. Body ornaments made from green stone are classified as callaite although the term is generic - see Vázquez Varela (1975) - and includes a number of minerals under this general denomination - see Domínguez-Bella (2012). Despite the fact that Iberian sources and distribution of callaite pieces has long been a major research topic, the distribution map of these pieces on the Iberian Peninsula remains poorly detailed. The distribution map of callaite pieces on the Iberian Peninsula drawn by Prof. Ana María Muñoz Amilibia in the 1960's was restricted to the outlying areas of the Iberian Peninsula; the Portuguese (western) and MillarenseArgaric (south-eastern) settlements and tombs, the Basque megaliths

\footnotetext{
* Corresponding author at: C/ María de Padilla S/N, 41004, Sevilla, Spain.

E-mail addresses: lbenitez@valdepenas.uned.es (L. Benítez de Lugo Enrich), anthropos@estudio-arqueologia.es (N. Palomares Zumajo),m.benito.sanchez@gmail.com (M. Benito Sánchez).
}

(northern) and the Catalan pit graves (north-eastern), (Muñoz Amilibia, 1965, Fig. 104). Over time, scientists documented the northwest region (Guitián Rivera and Vázquez Varela, 1975; Fábregas Valcarce, 1991, p. 100), as well as inland areas such as the Duero (Campano Lorenzo et al., 1985), Guadiana (Odriozola et al., 2010a), Tagus (Ríos Mendoza and Liesau von Lettow-Vorbeck, 2011), Ebro (Baldellou et al., 2012) and the Guadalquivir basins (Odriozola and García Sanjuán, 2013). Our analysis of green bead body ornaments from the Copper Age of El Castillejo del Bonete and Cerro Ortega (Fig. 1) in La Mancha on the Iberian Peninsula contributes to the completion of the Iberian distribution map.

\subsection{Archaeological context surrounding the findings}

Castillejo del Bonete and Cerro Ortega are located on the southern edge of the Meseta Central in the region of Campo de Montiel (southeast of the Ciudad Real province, Spain). The site is situated along the southern border of the territory where the Motillas culture has traditionally settled. Evidence shows that the place was used as burial grounds during Late Prehistory. Body ornamentation was found in Los 


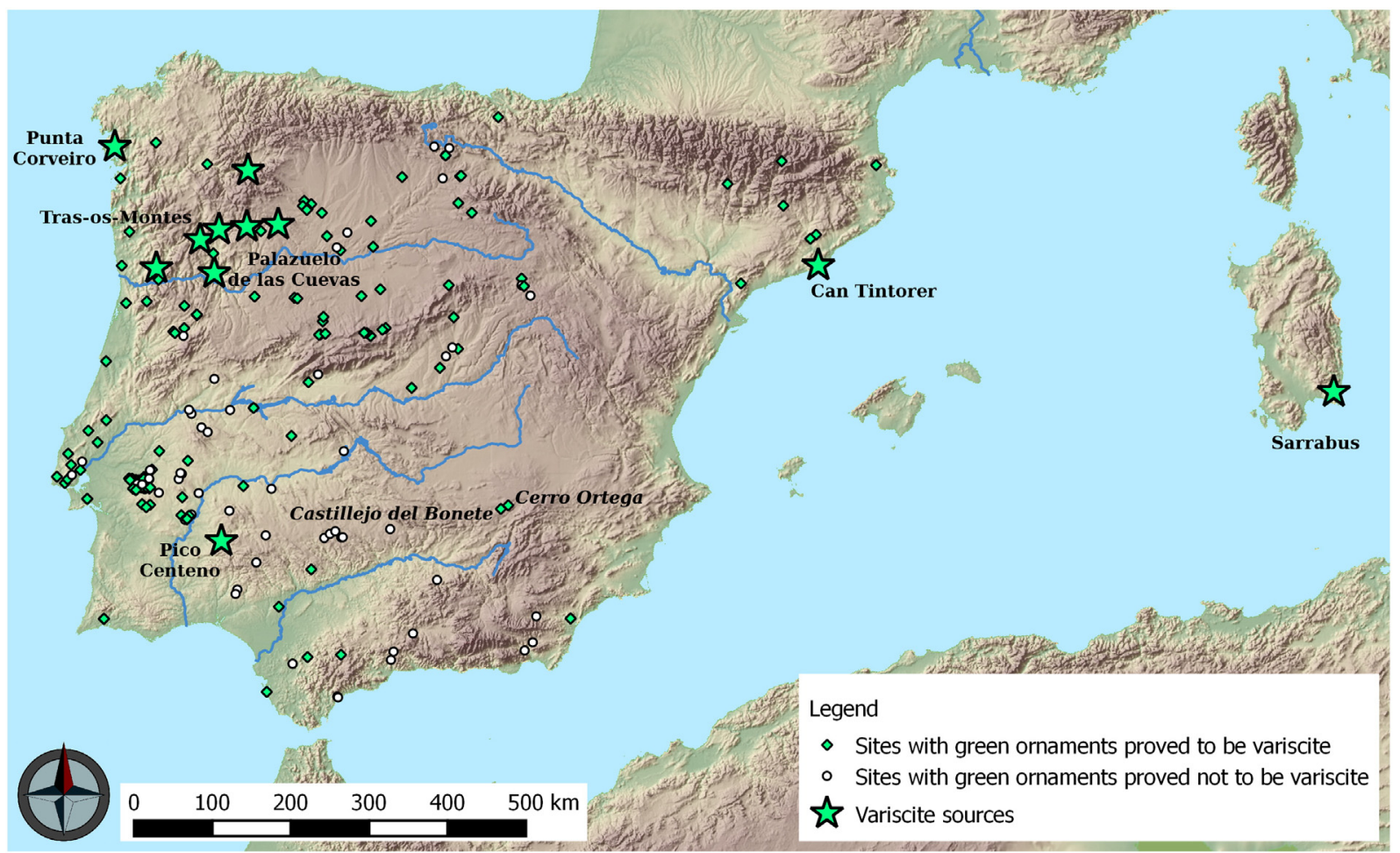

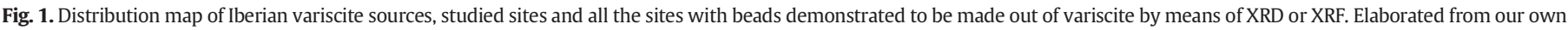

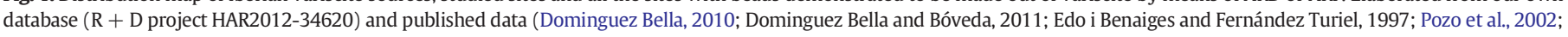
Ríos and Liesau von Lettow-Virbeck, 2011; Vijande Vila et al., 2015).

Parrales (Arenas de San Juan, Ciudad Real), which yielded 290 pendants made from bones and teeth (Benítez de Lugo et al., 2008). In addition, an amber bead was found (Poyato and Espadas, 1994) in El Castellón (Villanueva de los Infantes, Ciudad Real), and in La Encantada (Granátula de Calatrava, Ciudad Real) and El Retamar (Argamasilla de Alba, Ciudad Real) a number of stone beads of unspecified composition were discovered (Nieto Gallo \& Sánchez Meseguer, 1980, p. 180 Fig. 45, pieces G and H; Galán Saulnier and Sánchez Meseguer, 1994, p. 107 Fig. 2).

\subsubsection{Cerro Ortega}

The Cerro Ortega burial site (Villanueva de la Fuente, Ciudad Real) was discovered by chance in 1997 by Barrio and Maquedano (2000). The site had already partially been violated by treasure hunters by the time archaeological rescue excavation was carried out. Excavators found a stratigraphic unit sealed by the collapse of the shelter's canopy in the non-violated area. Human bones, faunal remains, lithic work, worked bone, 6 medium-sized black/dark grey beads (Fig. 2) and 8 small-sized slate beads (Fig. 3) (Gil Pitarch et al., 1999) were found.

Radiocarbon dating produced a 2-sigma calibrated age range from approximately the last quarter of the 4 th millennium cal. $\mathrm{BC}$ sequence (Poz-73598, $4475 \pm 35$ BP, human long bone, 2-sigma: 33413027 cal. BC). Human remains distributed into selective groups were recovered. Some long human bones show evidence of defleshing. The performance of commensality rituals close to the burial site was suggested by the discovery of approximately 200 fragments of animal bone as well as a number of pieces of coal. Long bone rods with flat or round sections - some with decorated proximal ends - and small schematic anthropomorphic figurines were also found. In addition, nine blades no longer than $17 \mathrm{~cm}$, some of whose edges had been retouched, were excavated along with other flint tools. Various pendants and beads made of bone were recovered as well. All of the materials were found accumulated together in a single stratigraphic unit.

\subsubsection{Castillejo del Bonete}

Castillejo del Bonete (Terrinches, Ciudad Real) is the site of a prehistoric tumulus complex (Benítez de Lugo Enrich et al., 2014, 2015). A metal copper arsenate needle (Montero Ruiz et al., 2014, p. 119 Fig. 8), fragments of carinated pottery with polished surfaces, undecorated Bell-Beakers and dotted ceramic were unearthed. Thirty-one beads and three roughouts (Fig. 4) made from green materials were recovered from UE 26019, documented in the West Survey excavated in Gallery 2. Absolute dating calibrated to two-sigma yielded 2465-2211 cal BC (3870 \pm 30 BP Beta-350768). All beads from Castillejo del Bonete were located in the interior of the cave under the main tumulus.

Furthermore, stratigraphic unit 26013 in Gallery 3 contained an 80$\mathrm{cm}$-thick paleochannel or drain (Fig. 5) with a 2-metre slope, a length of $6 \mathrm{~m}$ and a width of $1.8 \mathrm{~m}$. This level yielded pottery (105 shards), with protruding, sloped, round and ungulate sides, belonging to receptacles with smooth or polished surfaces, some of which were carinated. Faunal (vertebrae, herbivore metapods, a canine cranium and a coprolite), human (vertebrae, long bones, phalanges, cranium fragments) and lithic remains - such as a catapult projectile, flint arrowheads with appendices, a copper dagger and a seashell pendant - were also recovered.

\section{Materials and methods}

To understand their nature and identify their geographical origin, 41 ornaments from Castillejo del Bonete (Galleries 2 and 3) and Cerro Ortega were analysed using X-ray diffraction (XRD), X-ray fluorescence (XRF) and Confocal Dispersive $\mu$-Raman Spectroscopy (Dc $\mu R S)$.

$\mathrm{X}$-ray diffraction is an inexpensive, high-resolution technique which informs us of a piece's mineralogical composition. It is used to identify the mineral composition of a given material. After completing the baseline calculation with the X'Pert Highscore Plus 3.0 software and identifying all the peaks in the diagram, the numerical values obtained were compared with the 2004 ICDD (International Centre for Diffraction 
a

Limit of the excavations taken inside the shelter

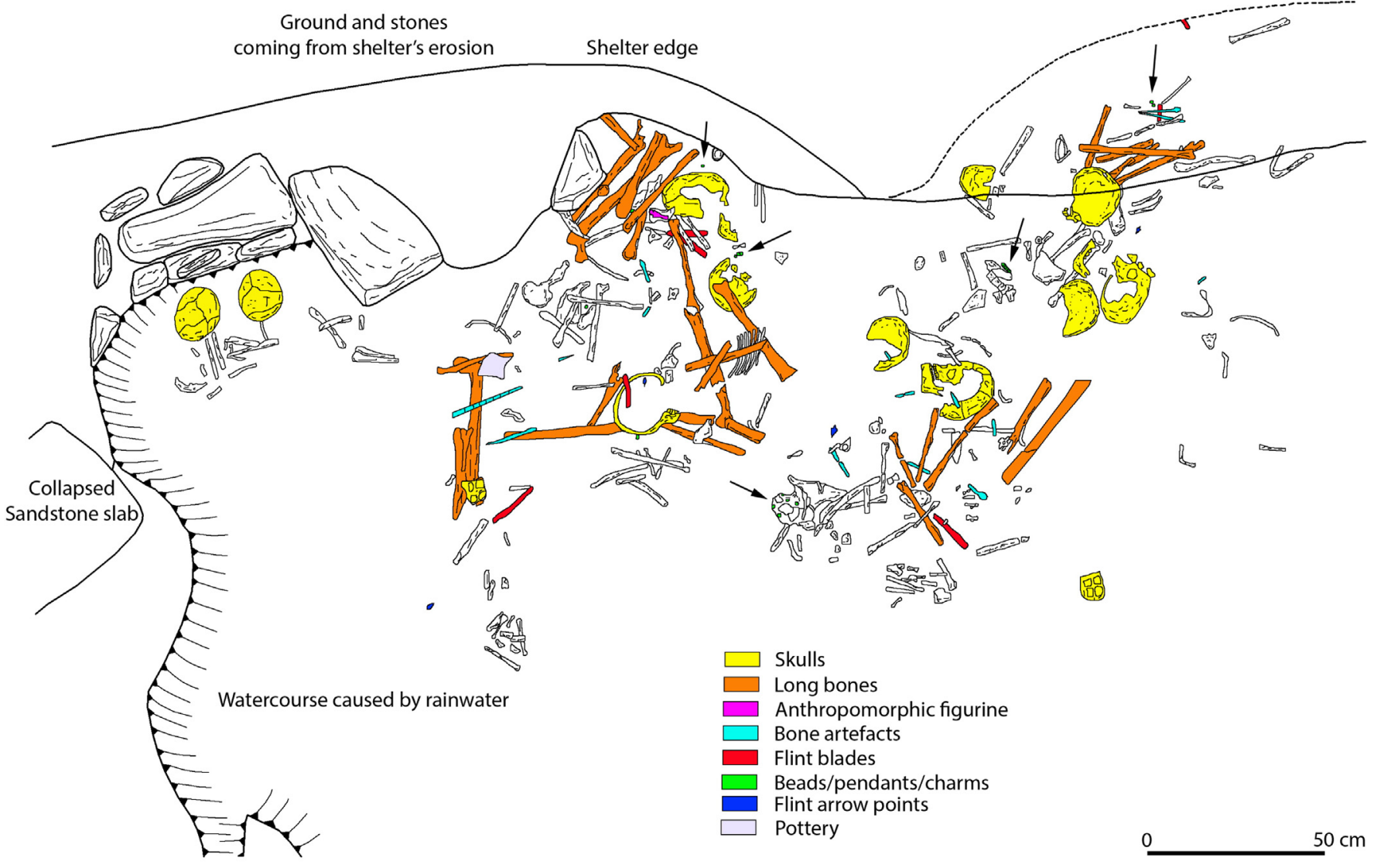

b

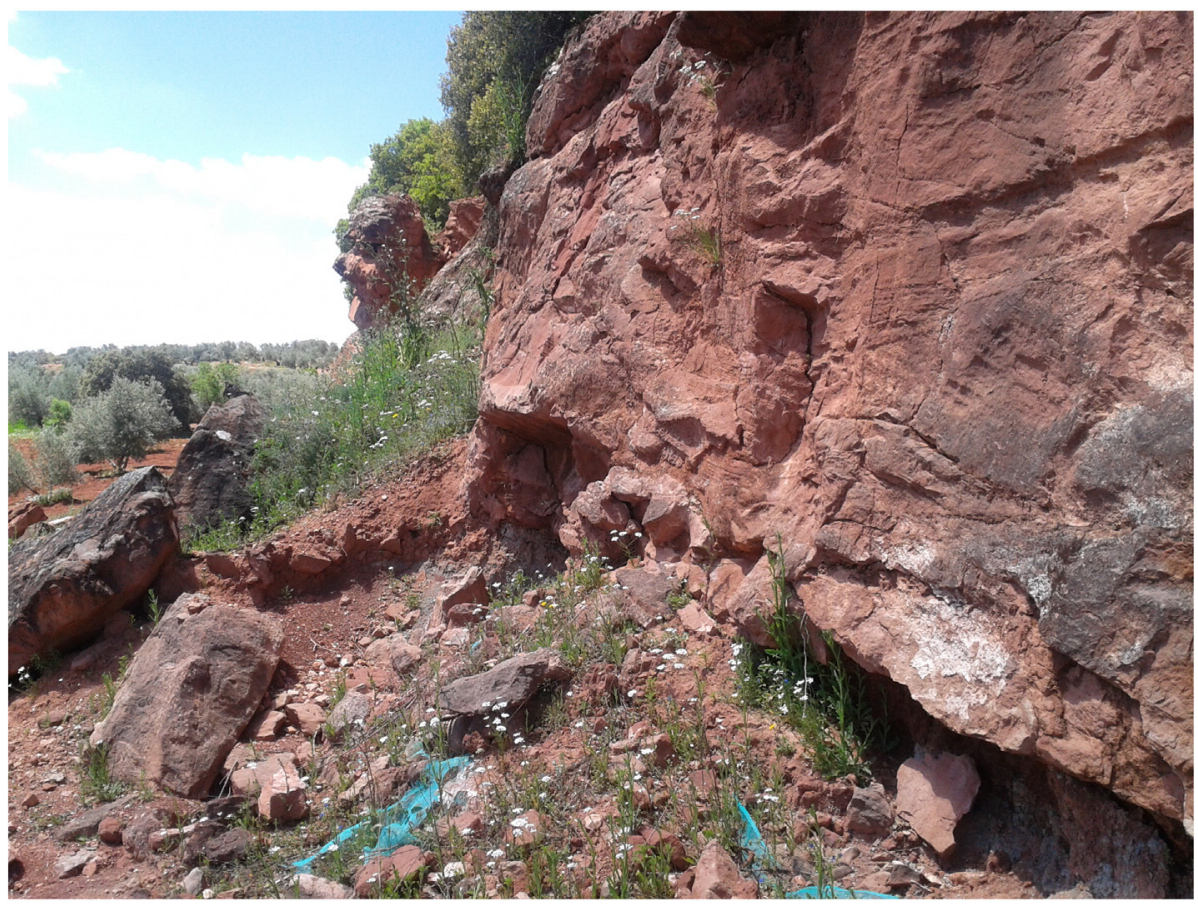

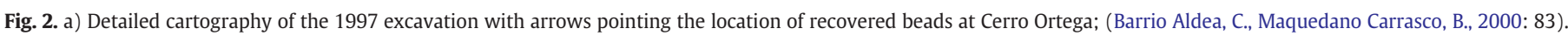

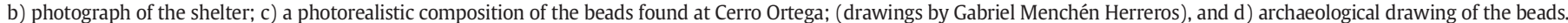


C
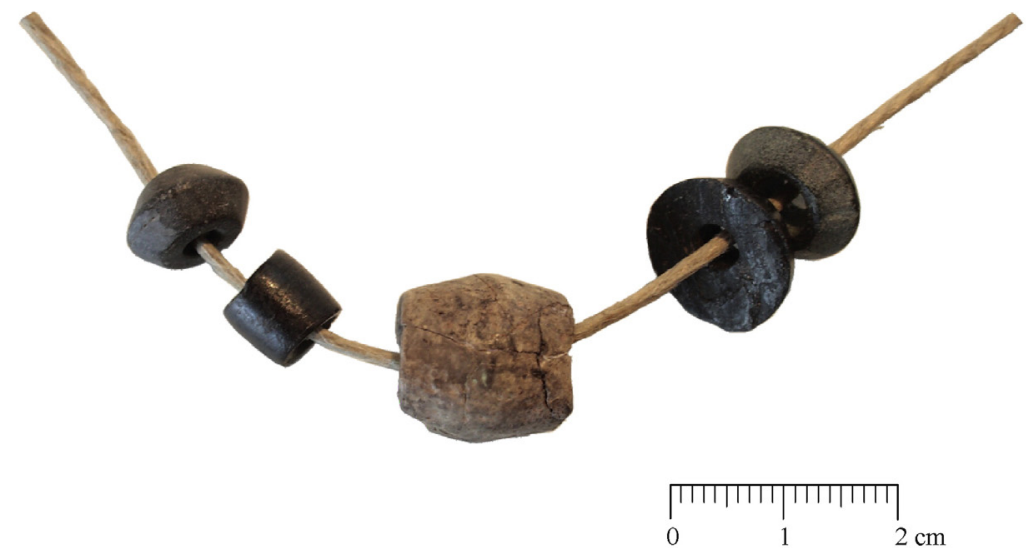

d

1

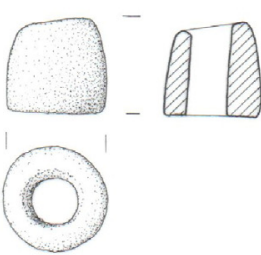

2

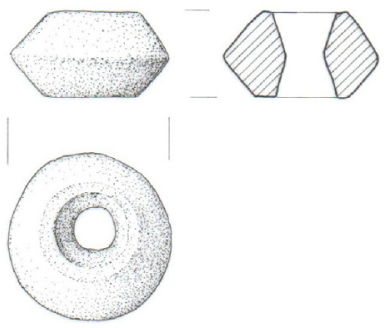

3

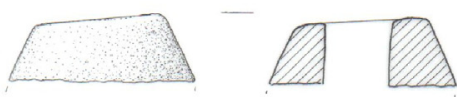

4

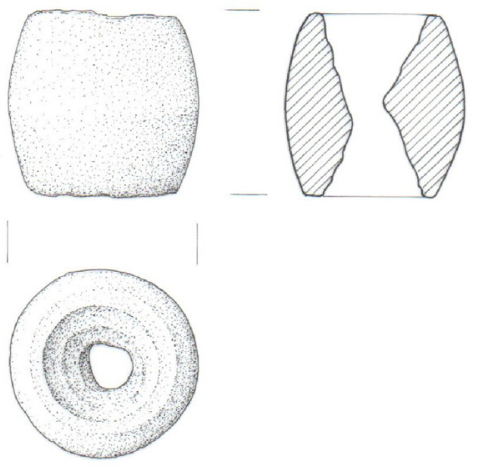

5
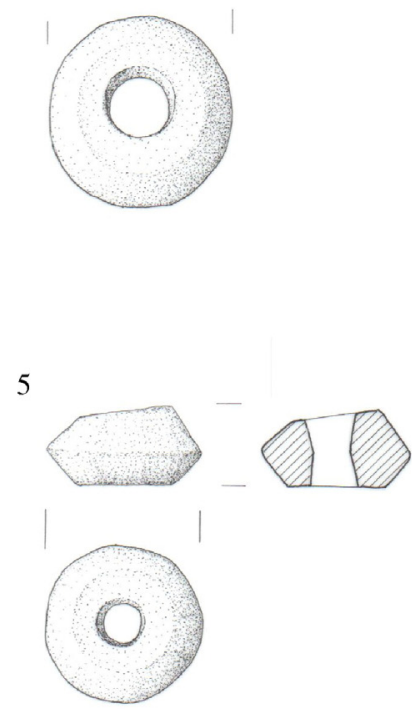

Fig. 2 (continued)

Data) PDF (Powder Diffraction File) database to identify the minerals that form the sample.

Confocal Dispersive $\mu$-Raman Spectroscopy, also a non-destructive technique, is used to identify solids through vibrations in the crystalline lattice as it can detect the sample's composition, bonds, coordination environment and crystalline structure (Edwards and Chalmers, 2005; Smith and Clark, 2004).

On the mineralogical level, the Panalytical X'Pert Pro $\theta / \theta$ X-ray diffraction equipment with $\mathrm{Cu} \mathrm{K} \alpha(1.5406 \AA$ ) radiation was chosen and operated at $45 \mathrm{kV}$ and $40 \mathrm{~mA}$, equipped with a PixCel detector and parabolic incident beam mirrors. The diagrams were acquired with a step of $0.026^{\circ} 2 \theta$ between $10^{\circ}$ and $70^{\circ} 2 \theta$ with an acquisition time of $247 \mathrm{~s}$ per step at room temperature $\left(25^{\circ} \mathrm{C}\right)$.

Data were completed using a HORIBA Jobin Yvon LabRAM HR Dispersive Confocal $\mu$-Raman Spectrometer system. The laser diode, when operated at a wavelength of $532.06 \mathrm{~nm}$, produces up to $15 \mathrm{~mW}$ of power in the source. Filters to reduce the laser's power were not used. The acquisition time was $32 \mathrm{~s}$ per acquisition, up to a maximum of 20 . 


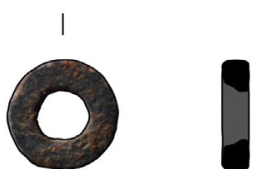

$6 \mathrm{~A}$

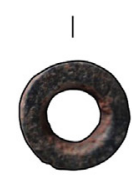

|

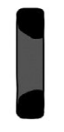

$6 \mathrm{~B}$

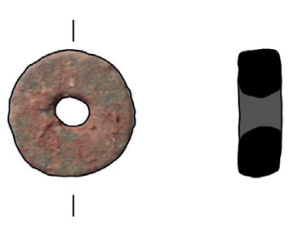

10

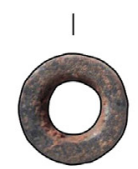

|

20

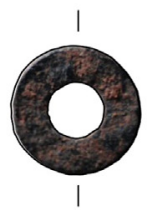

43
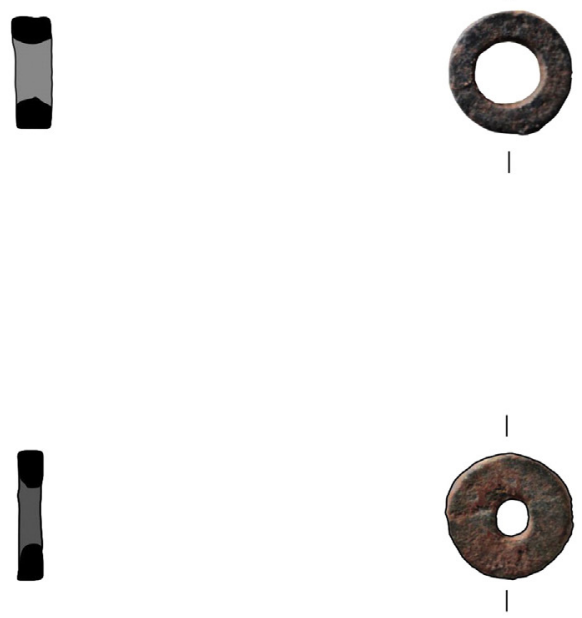

102

।

40
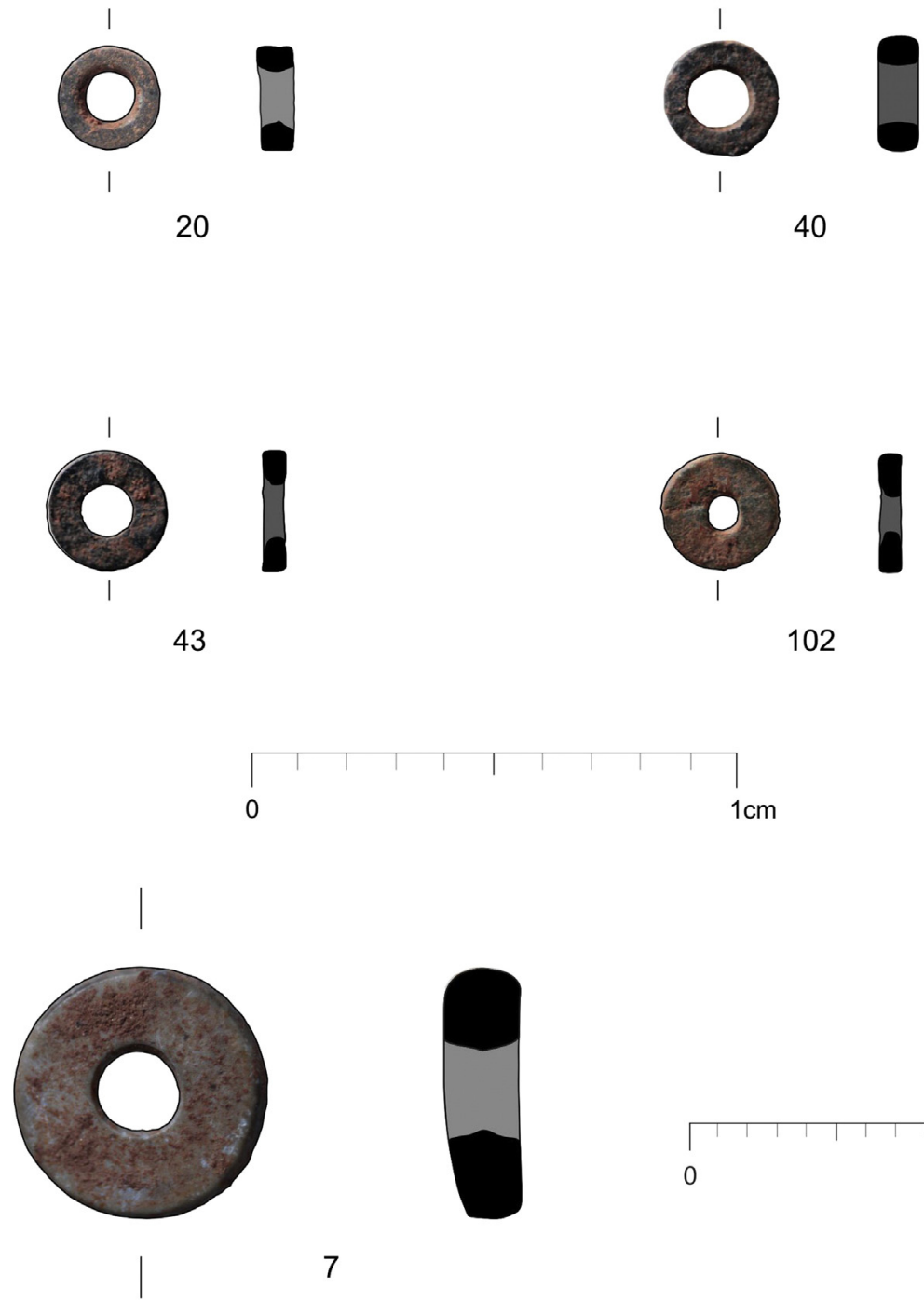

Fig. 3. Slate beads found at Cerro Ortega together with the green beads (drawings Gabriel Menchen).

The spectral measurement range chosen was between 100 and $1800 \mathrm{~cm}^{-1}$ using a $100 \times$ lens with a CCD multi-channel detector. The selected measurement is accurate to $1 \mathrm{~cm}^{-1}$. The measurement area selected was $1000 \mu \mathrm{m}$ in diameter.

EDAX Eagle III $\mu$-XRF equipment was used for the composition analysis. The piece was placed in a vacuum chamber and the optical microscope was then focused on it. A $100 \mu \mathrm{m}$ area of the piece was analysed using $\mathrm{K} \alpha$ radiation produced by an $\mathrm{Rh}$ tube operated at $40 \mathrm{kV}$. It was quantified with the equipment's software standard-less package. The quantitative results given are the average of five measurements.

\section{Results}

\subsection{Castillejo del Bonete}

\subsubsection{Gallery 2}

Mineralogical characterisation of Gallery 2 beads indicates that they are made from green stone; in 23 cases, variscite/ metavariscite $\left(\mathrm{AlPO}_{4} \cdot 2 \mathrm{H}_{2} \mathrm{O}\right)$. The diffraction patterns fully match files 25-18 of the variscite from Zamora (Salvador and Fayos, 1972). 


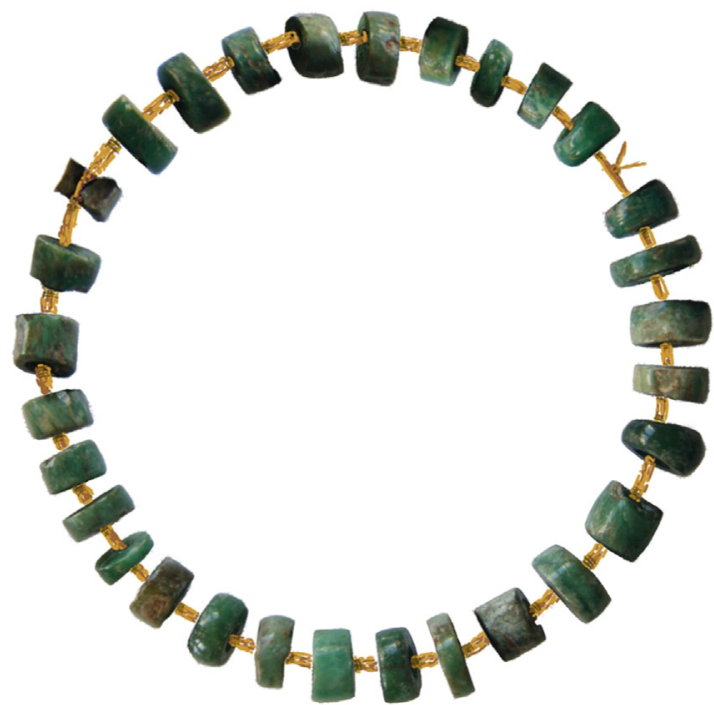

TE $12 \mathrm{BO} / 26019 / 10$

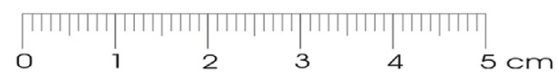

Fig. 4. Castillejo del Bonete unit 26019 bead assemblage (drawings by Gabriel Menchén Herreros).

Regarding the remaining 11 cases, 3 beads and the 3 roughouts were made using a different mineralogy: a mica-type phyllosilicate, specifically muscovite. Of the remaining 5 beads, one was identified as a calcium silicate while it has not been possible to determine the mineralogy of the other 4 pieces.

The diffractograms of the 23 green necklace beads of Castillejo del Bonete match files 25-18 (a mixture of variscite and metavariscite with a quartz intergrowth and high levels of $\mathrm{Fe}$ ). There were differences in peak intensity and minor movements in the main diffraction planes towards greater and lesser angles with no clear pattern to said file. This could indicate mineralogical differences in structure (Odriozola, 2014) i.e., secondary or minor minerals, or an amorphous, noncrystalline material in the beds' raw material.

This can be proved in extreme cases such as sample TE12B0-2601924 which, with a P/Al atomic ratio of 5.29, has a diffraction pattern that

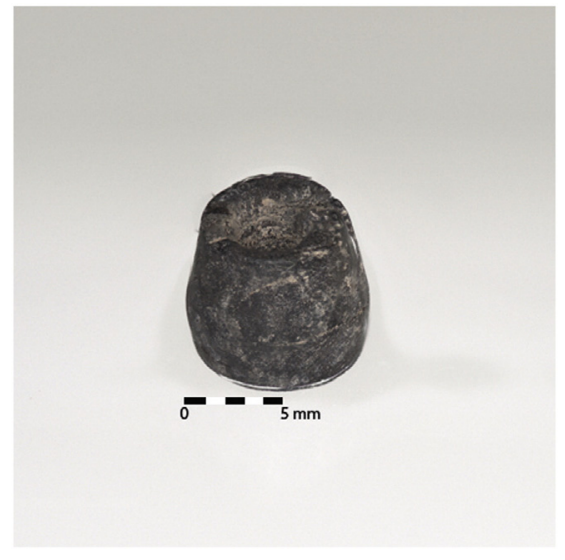

Fig. 5. Castillejo del Bonete gallery 2 bead. unquestionably indicates that it is variscite (Fig. 6). With around $4 \% \mathrm{Al}$, $20 \% \mathrm{P}, 20 \% \mathrm{Ca}$ and $39 \% \mathrm{Si}$, we cannot say if it is a material composed mainly of variscite and quartz. The diffractogram reflects that the material contains variscite and quartz, but it would also appear that the P-to$\mathrm{Al}$ ratio is certainly unbalanced. There is a significant amount of $\mathrm{P}$ that has not crystallised as variscite; simultaneously, there is a large quantity of Ca that does not appear in crystalline form in the sample. This could indicate that the material used contains a significant proportion of some sort of non-crystalline calcium phosphate. There are numerous non-crystalline calcium phosphates that form hydrothermally in $\mathrm{pH}$ acidic conditions, (Alqap and Iis, 2009). The possibility remains that during this raw material's paragenesis, variscite, together with some kind of amorphous calcium phosphate, and quartz, precipitated. This would explain such a high P-to-Al atomic ratio. Something similar occurs with the TE12B0-26019-16 sample, which has a Ca content of nearly $6 \%$ and a $\mathrm{P} / \mathrm{Al}$ atomic ratio of around 3.3; generally speaking, these samples are high in Ca.

Fig. 6 shows the high baseline of the measurement - around 1600 counts. This indicates that a large quantity of amorphous materials is present, thus supporting the hypothesis we have outlined.

The values of this $\mathrm{P} / \mathrm{Al}$ atomic ratio for the 23 beads that give a diffractogram compatible with variscite are diverse and vary between a little less than the unit and a little less than six. Despite the fact that accepted values for Iberian variscite are around $0.8-1.8$, values above 2 indicate the presence of abnormally-high quantities of Fe or Ca. In the case of the $\mathrm{Fe}$, it would appear to be substituting the $\mathrm{Al}$, leading to strengite $\left[\mathrm{FePO}_{4} \cdot 2 \mathrm{H}_{2} \mathrm{O}\right]$ as a minor crystalline phase. We are not able to detect this phase from the diffractograms, so it is unlikely that our samples contain strengite (Odriozola, 2014).

On the other hand, the high presence of Ca could be explained by the mineral's origin, given that along with variscite it often crystallises crandallite $\left[\mathrm{CaAl}_{3}\left(\mathrm{PO}_{4}\right)_{2}(\mathrm{OH})_{5} \cdot \mathrm{H}_{2} \mathrm{O}\right]$, wavellite, $\left[\mathrm{Al}_{3}\left(\mathrm{PO}_{4}\right)_{2}(\mathrm{OH}, \mathrm{F})_{3} \cdot 5 \mathrm{H}_{2} \mathrm{O}\right]$, apatite $\left[\mathrm{Ca}_{10}\left(\mathrm{PO}_{4}\right)_{6}(\mathrm{OH}, \mathrm{F}, \mathrm{Cl})_{2}\right] \ldots$ which are calcium phosphates that often appear in the same phosphate deposits as variscite - see the European mines of Pannece, Sarrabús and Can Tintorer (Camprubi et al., 1994; Fernández Turiel et al., 1990; Marini et al., 1989; Massé, 1971) at the mines of Fairfield (Utah, USA) (Larsen, 1942a, 1942b, 1942c) and the deposits of Woodland in Australia(Willing et al., 2008). On the Terena Synform, where Pico Centeno is situated, zones in which different phosphates appear together with variscite have been found, e.g. aheylite $\left[\mathrm{Fe}_{2}+\mathrm{Al}_{6}\left(\mathrm{PO}_{4}\right)_{4}(\mathrm{OH})_{8} \cdot 4 \mathrm{H}_{2} \mathrm{O}\right]$ and turquoise $\left[\mathrm{CuAl}_{6}\left(\mathrm{PO}_{4}\right)_{4}(\mathrm{OH})_{8} \cdot 4 \mathrm{H}_{2} \mathrm{O}\right]$, but calcium phosphates have never been detected (Odriozola and Villalobos García, 2015), even though Moro et al. (1995) define these deposits as aluminium phosphates ( $\mathrm{Fe}, \mathrm{Ca}$ ). Conversely, in the Alcañices Synform, we have detected calcium phosphates, e.g. crandallite $\left[\mathrm{CaAl}_{3}\left(\mathrm{PO}_{4}\right)_{2}(\mathrm{OH})_{5} \cdot(\mathrm{H} 2 \mathrm{O})\right]$.

Of these 23 beads that correspond to aluminium phosphates, 7 have very high $\mathrm{P}$-to-Al atomic ratios and high $\mathrm{Fe}$ and Ca contents, which would mean iron and calcium phosphates could be present as minor crystalline phases or amorphous material (Table 1 ). In this respect, in previous articles (Odriozola, 2014; Odriozola et al., $2010 \mathrm{~b}$ ) we have argued that the anomalous P-to-Al atomic ratio values found in variscite from Iberian sources were due to structural variations stemming from their paragenesis. Thus the P-to-Al atomic ratio is a suitable method for distinguishing between sources due to the particular paragenesis of each source. In this respect, and bearing in mind what has been said previously, it would appear evident that the high Ca values of the Castillejo del Bonete samples indicate that they originate from a source in which calcium phosphates can be found alongside variscite.

If we compare the P-to-Al atomic ratio values of the 23 examples of variscite of Castillejo del Bonete with the data available from the Iberian mines, we can see that the beads of Castillejo del Bonete may have had different origins. On the one hand, those with values between 0.8 and 1.4 could be from Aliste (Zamora), although those lower values ( $>1.1$ ) could also indicate they originated in Can Tintorer (Barcelona), as can 


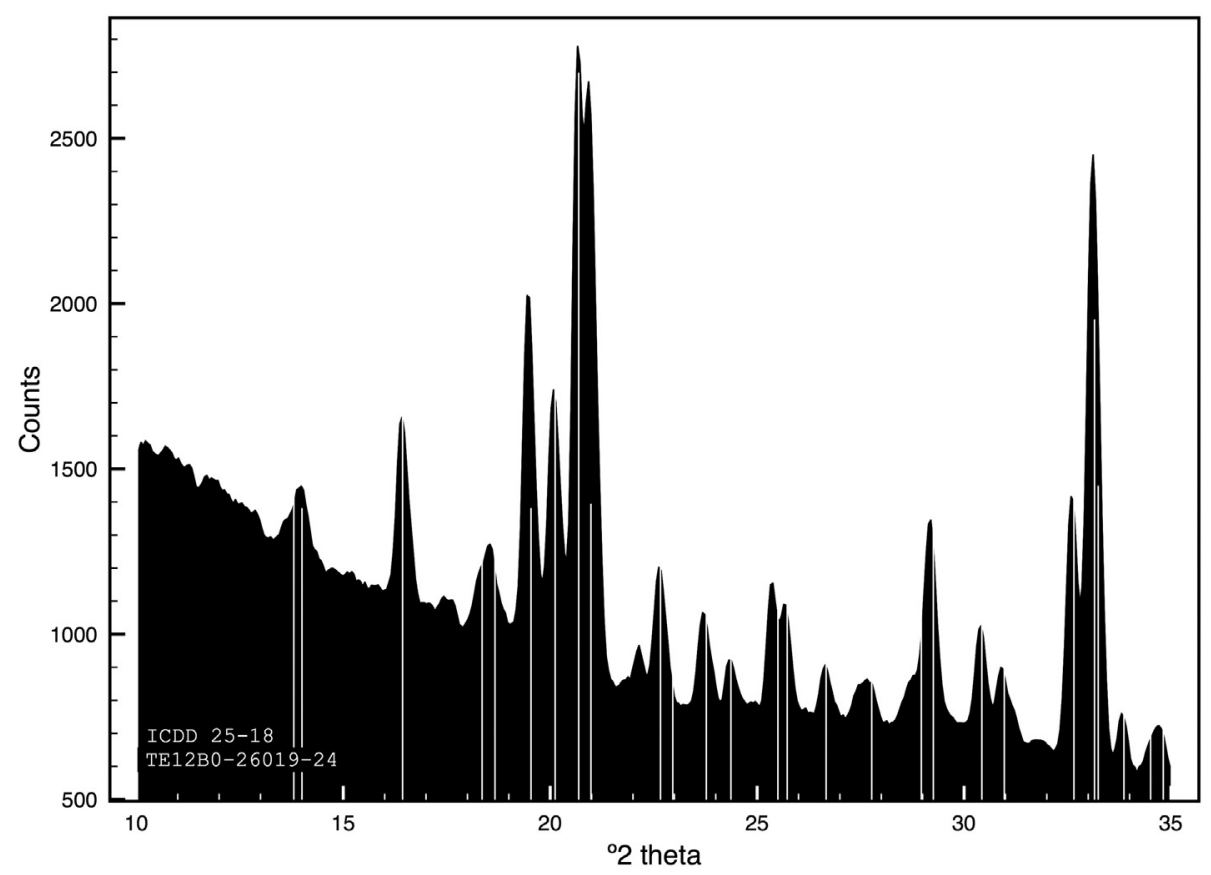

Fig. 6. XRD pattern of sample TE12B0-26019-24 compared to Salvador and Fayos (1972) ICDD 25-18 card.

Table 1

Elemental composition (atomic \%), P-to-Al atomic ratio, most probable proxy and mineralogy of Castillejo del Bonete studied samples and Fuente Álamo V5 bead cited along the text.

\begin{tabular}{|c|c|c|c|c|c|c|c|c|c|c|c|c|}
\hline & & $\mathrm{Al}$ & $\mathrm{Si}$ & $\mathrm{P}$ & $\mathrm{Ca}$ & $\mathrm{Ti}$ & V & $\mathrm{Cr}$ & $\mathrm{Fe}$ & $\mathrm{P} / \mathrm{Al}$ & Proxy & Mineralogy \\
\hline 1 & TE12B0-26019-1 & 22.62 & 51.77 & 22.25 & 0.57 & 1.53 & 0.16 & 0.3 & 0.79 & 0.98 & $\mathrm{CT}$ & V \\
\hline 2 & TE12B0-26019-3 & 22.38 & 38.23 & 35.08 & 1.99 & 0.25 & 0.09 & 0.28 & 1.7 & 1.57 & PC & $\mathrm{V}+\mathrm{Q}^{\mathrm{a}}$ \\
\hline 3 & TE12B0-26019-4 & 27.00 & 30.53 & 38.39 & 2.01 & 0.22 & 0.13 & 0.52 & 1.2 & 1.42 & PDLC & $\mathrm{V}$ \\
\hline 4 & TE12B0-26019-5 & 18.17 & 29.95 & 46.32 & 2.96 & 0.49 & 0.45 & 0.27 & 1.39 & 2.55 & $?$ & $M(89 \%)+Q(11 \%)$ \\
\hline 5 & TE12B0-26019-6 & 30.73 & 27.52 & 39.88 & 0.94 & 0.12 & 0.09 & 0.26 & 0.47 & 1.3 & PDLC & $\mathrm{V}$ \\
\hline 6 & TE12B0-26019-7 & 22.33 & 29.4 & 42.77 & 1.73 & 0.39 & 0.24 & 0.42 & 2.72 & 1.91 & PC & V \\
\hline 7 & TE12B0-26019-8 & 24.61 & 51.93 & 20.3 & 2.49 & 0.09 & 0.13 & 0.17 & 0.27 & 0.82 & $\mathrm{CT}$ & $\mathrm{V}+(\mathrm{Cu}, \mathrm{Mg})-\mathrm{Si}$ \\
\hline 8 & TE12B0-26019-10 & 22.98 & 6.22 & 64.31 & 1.75 & 0.48 & 0.5 & 1.1 & 2.66 & 2.8 & $?$ & $\mathrm{~V}$ \\
\hline 9 & TE12B0-26019-12 & 25.37 & 49.27 & 22.62 & 1.43 & 0.12 & 0.1 & 0.17 & 0.92 & 0.89 & $\mathrm{CT}$ & V \\
\hline 10 & TE12B0-26019-13 & 26.99 & 12.33 & 55.64 & 0.89 & 0.32 & 0.14 & 0.34 & 3.35 & 2.06 & PC & V \\
\hline 11 & TE12B0-26019-14 & 9.08 & 17.95 & 48.03 & 6.98 & 0.77 & 0.69 & 1.27 & 15.23 & 5.29 & $?$ & M \\
\hline 12 & TE12B0-26019-15 & 33.19 & 18.35 & 45.83 & 1.06 & 0.23 & 0.13 & 0.24 & 0.97 & 1.38 & PDLC & V \\
\hline 13 & TE12B0-26019-16 & 13.38 & 34.19 & 43.16 & 5.93 & 0.18 & 0.69 & 0.94 & 1.54 & 3.23 & $?$ & V \\
\hline 14 & TE12B0-26019-17 & 17.04 & 25.68 & 41.3 & 4.76 & 0.67 & 1.17 & 0.81 & 8.57 & 2.42 & $?$ & $V+Q$ \\
\hline 15 & TE12B0-26019-18 & 38.26 & 8.55 & 50.76 & 0.56 & 0.29 & 0.11 & 0.22 & 1.26 & 1.33 & PDLC & $\mathrm{V}$ \\
\hline 16 & TE12B0-26019-21 & 29.93 & 35.16 & 32.49 & 1.64 & 0.13 & 0.05 & 0.18 & 0.42 & 1.09 & $\mathrm{CT}$ & V \\
\hline 17 & TE12B0-26019-22 & 20.47 & 25.3 & 49.4 & 2.92 & 0.23 & 0.14 & 0.39 & 1.15 & 2.41 & $?$ & V \\
\hline 18 & TE12B0-26019-23 & 27.57 & 35.24 & 33.27 & 2.19 & 0.42 & 0.12 & 0.25 & 0.94 & 1.21 & PDLC & V \\
\hline 19 & TE12B0-26019-24 & 3.6 & 38.55 & 19.89 & 20.35 & 2.13 & 0.93 & 1.51 & 13.02 & 5.53 & $?$ & $\mathrm{~V}$ \\
\hline 20 & TE12B0-26019-25 & 22.18 & 39.88 & 32.24 & 3.14 & 0.18 & 0.07 & 0.17 & 2.14 & 1.45 & $?$ & $V+M$ \\
\hline 21 & TE12B0-26019-27 & 36.88 & 9.82 & 50.85 & 0.6 & 0.1 & 0.17 & 0.26 & 1.32 & 1.38 & PDLC & V \\
\hline 22 & TE12B0-26019-28 & 20.18 & 50.01 & 23.58 & 4.03 & 0.31 & 0.23 & 0.23 & 1.44 & 1.17 & PDLC & V \\
\hline \multirow[t]{2}{*}{23} & TE12B0-26019-29 & 20.81 & 15.05 & 53.16 & 2.65 & 0.39 & 0.17 & 0.52 & 7.26 & 2.55 & - & V \\
\hline & & $\mathrm{Al}$ & $\mathrm{Si}$ & $\mathrm{P}$ & $\mathrm{K}$ & $\mathrm{Ca}$ & $\mathrm{Ti}$ & V & $\mathrm{Cr}$ & Mn & $\mathrm{Fe}$ & Mineralogy \\
\hline 24 & TE12B0-26019-2 & 14.73 & 74.88 & 1.32 & 0 & 5.23 & 0.78 & 0.47 & 2.48 & 0.11 & 0.09 & $\mathrm{Ca}-\mathrm{Si}$ \\
\hline 25 & TE12B0-26019-9 & 21.34 & 45.5 & 27.64 & 0 & 2.53 & 0.28 & 0.29 & 0.41 & 2.01 & 1.29 & $?$ \\
\hline 26 & TE12B0-26019-11 & 12.8 & 54.4 & 16.49 & 0 & 6.62 & 0.76 & 0.52 & 0.87 & 7.53 & 1.29 & $?$ \\
\hline 27 & TE12B0-26019-19 & 15.59 & 73.72 & 2.96 & 1.55 & 5.61 & 0 & 0 & 0.23 & 0.01 & 0.32 & Mo \\
\hline 28 & TE12B0-26019-20 & 20.57 & 61.47 & 13.86 & 0 & 2.98 & 0.16 & 0.06 & 0.15 & 0.75 & 0.67 & $?$ \\
\hline 29 & TE12B0-26019-26 & 25.39 & 31.64 & 38.39 & 0 & 1.88 & 0.22 & 0.06 & 0.19 & 2.23 & 1.51 & $?$ \\
\hline 30 & TE12B0-26019-30 & 0 & 35.3 & 0 & 19.2 & 13.7 & 3.68 & 0.52 & 0 & 0 & 27.68 & Mo \\
\hline 31 & TE12B0-26019-31 & 15.2 & 71.3 & 0 & 6.7 & 2.4 & 0.71 & 0.03 & 0 & 0 & 3.67 & Mo \\
\hline 32 & TE12B0-26019-32 & 15.6 & 74.6 & 0 & 5.1 & 1.4 & 0.67 & 0.02 & 0 & 0 & 2.53 & Mo \\
\hline 33 & TE12B0-26019-33 & 18.3 & 56.6 & 0 & 21.7 & 2.4 & 0.19 & 0.08 & 0 & 0 & 0.51 & Mo \\
\hline \multirow[t]{2}{*}{34} & TE12B0-26019-34 & 11.9 & 71.7 & 0 & 10.3 & 5.2 & 0.21 & 0.05 & 0 & 0 & 0.38 & Mo \\
\hline & & $\mathrm{Al}$ & $\mathrm{Si}$ & $\mathrm{P}$ & $\mathrm{K}$ & $\mathrm{Ca}$ & $\mathrm{Ti}$ & V & $\mathrm{Cr}$ & Mn & $\mathrm{Fe}$ & Mineralogy \\
\hline 35 & V5 (Fte. Álamo) ${ }^{\mathrm{a}}$ & 36.92 & 6.33 & 50.41 & & 2.02 & & & & & 2.93 & V \\
\hline
\end{tabular}

\footnotetext{
a Original values expressed on \%. Here transformed to \% atomic.
} 


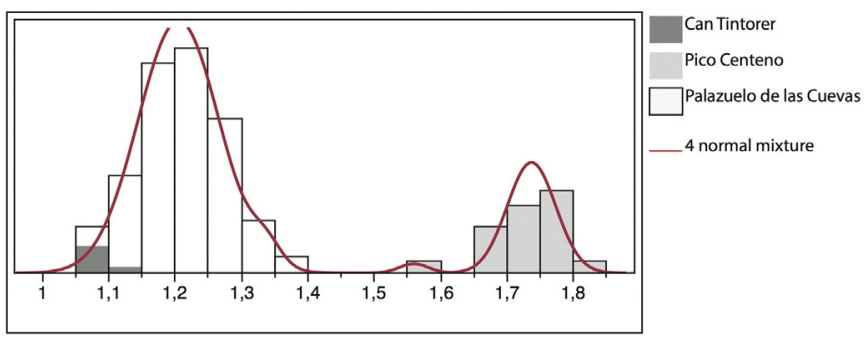

Fig. 7. P-to-Al atomic ratio distribution plot of Iberian variscite mines. In red 4 normal density fit curve. (For interpretation of the references to colour in this figure legend, the reader is referred to the web version of this article.)

be deduced from the P-to-Al ratio distribution graph (Fig. 7). On the other hand, values greater than 1.5 and lower than 2.0 could be related to Pico Centeno's (Huelva) values.

It is important to bear in mind that the Barcelona and Zamora mines overlap, with P-to-Al ranges close to 1 (Fig. 7). Therefore, it could be incorrect to assume that they are of Barcelona origin; in this case, it is important to treat the results with caution. Consequently, Edo et al. (1995) propose the use of $\mathrm{Si}$ and $\mathrm{Ca}$ to distinguish between the minerals of Can Tintorer, which are more calcareous, and those of Aliste, with quartz intergrowth. Meanwhile, Herbaut et al. (2004) propose the use of V, Cr and Fe to distinguish the pieces' origins. In any case, on the basis of the polycrystalline mixtures, it would seem that, although the P-to-Al atomic ratio gives us an indication of the origins of the green phosphate deposits from the peninsula, elements such as $\mathrm{Ca}$ and $\mathrm{Si}$ should also be explored in conjunction with one another, given that aluminium phosphates usually precipitate together with calcium phosphates and have quartz intergrowth in many cases. If we look at the following ternary diagram (Fig. 8), whose vertices represent the P-to-Al atomic ratio and the $\mathrm{Si}$ and $\mathrm{Ca}$ atomic content, we can see that the separation between sources is absolute.

The non-parametric density estimation plotted in Fig. 8 for each of the studied sources clearly shows that using P-to-Al atomic ratios in conjunction with silica and calcium atomic values can be a reliable argument for source differentiation as the combined variation of these elements is smaller within source than between sources. It can, however, be observed that a small overlap occurs between Palazuelo de las Cuevas and Can Tintorer on the lower silica values, albeit we expect to shorten Can Tintorer dispersion when new data become available reducing this already small overlap to insignificant.

The P-to-Al, Si and Ca atomic values from Castillejo del Bonete grossly fit the Palazuelo de las Cuevas value distribution. There are, however, a group of values from Castillejo del Bonete that do not fit into any of the calculated sources' density estimates, implying that perhaps we could be dealing with a material whose origins are unknown. However, both Pico Centeno and Aliste can be ruled out, bearing in mind the data now available.

Studies carried out recently on Fuente Álamo's beads (Pozo et al., 2002 ) indicate that, in the same time period as those of Castillejo del Bonete, many different raw materials were used for beadworking as attested to in Iberian Late Prehistory - see Dominguez Bella (2012). At Fuente Álamo the use of muscovite, bone, fluorite, silver, variscite and micas has been documented. In particular, variscite bead V5 of Fuente Álamo had rather high Ca and Si values, without reaching the extreme values of Castillejo del Bonete for Si. Pozo et al. (2002) propose that this variscite sample originates from Can Tintorer and that the muscovite samples, based on their purity, are from the Middle East.

We do not believe it feasible that the variscite beads of Casillejo del Bonete and Fuente Álamo geographical origins are located at Can Tintorer, not only because the P-to-Al atomic ratio, Ca and Si values make it unfeasible, but rather because it would not make sense chronologically, given that the time period of the Can Tintorer mines is earlier than that of Castillejo del Bonete (Fig. 9). One could argue, however, that the variscite bead was a relic.

In any case, the data available for Can Tintorer are limited and widely dispersed, so we cannot be absolutely certain at this juncture that the bead with higher Ca values does not originate from Can Tintorer.

\subsubsection{Gallery 3}

The $\mathrm{DC} \mu \mathrm{RS}$ of the bead that was recovered in Gallery 3 indicates that the raw material is cellulose. In other words, we are dealing with wooden beads (Fig. 10).

We have radiocarbon dated this wooden bead. The result shows that the bead was most likely made out of fossil wood (CNA-3222.1.1, $36,520 \pm 670$ BP, 2 sigma: 40,214-37,783 cal. BC).

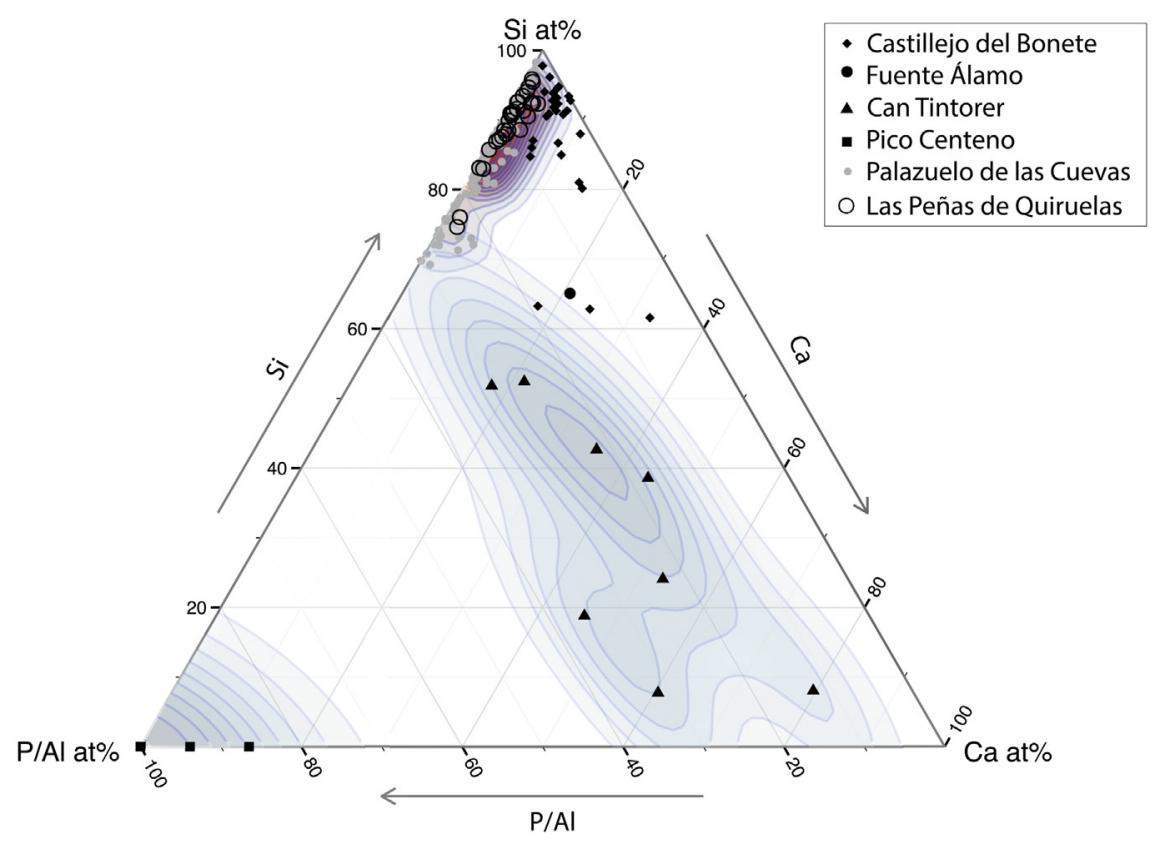

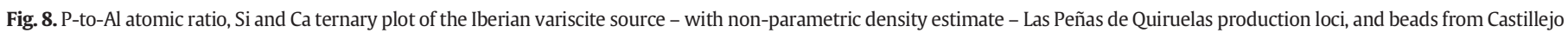
del Bonete. 


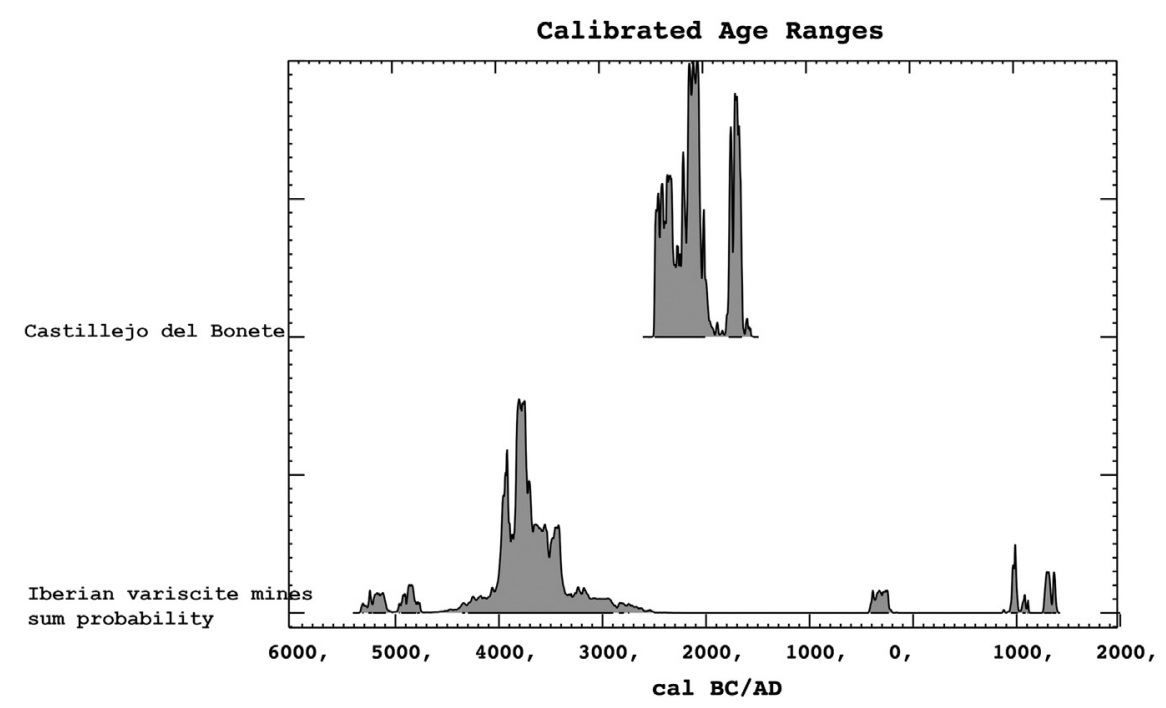

Fig. 9. Radiocarbon dates sum probability plot for Can Tintorer (Borrell et al., 2009) and Castillejo del Bonete.

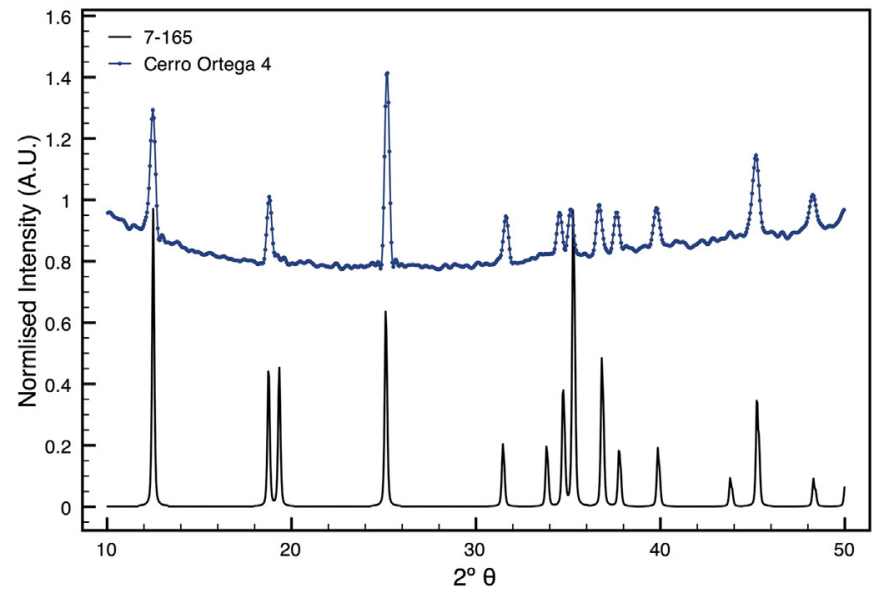

Fig. 10. Cerro Ortega sample 4 XRD pattern compared to ICDD 7-165 card (clinochlore).

\subsection{Cerro Ortega}

The beads from Cerro Ortega were made from different raw materials. The X-ray diffraction (Table 2) tells us that two of them were made from clinochlore (Fig. 10), one from calcite and another from enstatite (Fig. 11).

On the other hand, the DC $\mu R S$ indicates that two of the beads were made from wood, as the Raman signal matches that of cellulose.

Clinochlore $\left[\left(\mathrm{Mg}, \mathrm{Fe}^{+2}\right)_{5} \mathrm{Al}\left(\mathrm{Si}_{3} \mathrm{Al}\right) \mathrm{O}_{10}(\mathrm{OH})_{8}\right]$ is a silicate mineral from the chlorite family which normally appears in metamorphic or magnesian rock contexts.
It is a material which, by its very nature, is not particularly abundant, which is why it could be classified as a 'rare' or 'exotic' rock. This factor would place it in the same high regard as other rare rocks or exotic raw materials such as variscite, amber and ivory. However, this consideration is undoubtedly due to its rarity (Taffinder, 1998). In this respect, Dominguez Bella (2010) cites various places in which the material has been documented: Sierra de Guadarrama (Torrelodones, Colmenarejo, Galapagar), the province of Guadalajara (in the HiendelaencinaAlcorlo area), Serranía de Ronda, Sierra Morena, Badajoz (Burguillos del Cerro), Barcelona, Biscay, Almería and Asturias. Its natural distribution seems slightly higher than variscite's, but even so it is low enough to be considered an exotic material.

We have known about this mineral's use in producing body ornaments for a relatively short time. Until now, it had only been documented in the Bronze Age cist necropolis of Carapinhais (Sobral da Adiça, Moura) (Gonçalves et al., 2011; Huet Gonçalves, 2007), the fortified Late Bronze Age settlement of Castro dos Ratinhos (Moura) (Gonçalves et al., 2011) and in the artificial cave necropolis of Valle de las Higueras (Huecas, Toledo) (Dominguez Bella, 2010); no trace of it had previously been found. Dominguez Bella (2010) states that he has analysed clinochlore beads in the Basque Country, but he does not specify the site or number.

The studies that we are conducting as part of the HAR2012-34,620 $\mathrm{R}+\mathrm{D}$ project can be added to these events. The use of this type of mineral has been documented at Cova da Moura (Torres Vedras), Las Cabezas II (Alburquerque, Badajoz), in a pit tomb on Dinamarca Street in Valencina de la Concepción (Valencina de la Concepción, Sevilla) and in La Sima - the Cave of Don Juan (Cazalla de la Sierra, Seville), as well as those of Cerro Ortega (Fig. 12).

With regard to its use, our available data places it in a time frame that ranges from the 5th/4th millennium cal. BC in Cova da Moura to

Table 2

Elemental composition (atomic \%) and mineralogy of Cerro Ortega studied samples.

\begin{tabular}{|c|c|c|c|c|c|c|c|c|c|c|c|c|c|c|c|c|}
\hline ID & & $\mathrm{Mg}$ & $\mathrm{Al}$ & $\mathrm{Si}$ & Mo & $\mathrm{K}$ & $\mathrm{Ca}$ & $\mathrm{Ti}$ & V & $\mathrm{Cr}$ & $\mathrm{Mn}$ & $\mathrm{Fe}$ & $\mathrm{Cu}$ & $\mathrm{Zn}$ & $\mathrm{Br}$ & $\mathrm{Sr}$ \\
\hline 1 & $E$ & - & - & 13.49 & 17.03 & - & 45.55 & - & - & - & - & 23.14 & - & - & - & 0.79 \\
\hline 2 & C & - & - & - & - & - & - & - & - & - & - & - & - & - & - & - \\
\hline 3 & $C$ & - & - & - & - & - & - & - & - & - & - & - & - & - & - & - \\
\hline 4 & $\mathrm{Cl}$ & 21.50 & 26.92 & 31.46 & - & - & - & - & - & - & - & 20.12 & - & - & - & - \\
\hline 5 & $\mathrm{Cl}$ & 17.65 & 27.21 & 45.33 & - & 4.64 & - & 0.97 & 0.07 & - & - & 4.13 & - & 0.00 & - & - \\
\hline 6 & $\mathrm{Ca}$ & - & 15.99 & 60.30 & - & 3.57 & 1.85 & 0.62 & 0.03 & 0.01 & 0.08 & 17.48 & 0.04 & 0.02 & - & 0.01 \\
\hline
\end{tabular}

E: ensteatite; C: cellulose; $\mathrm{Cl}$ : clinochlore; Ca: calcite. 


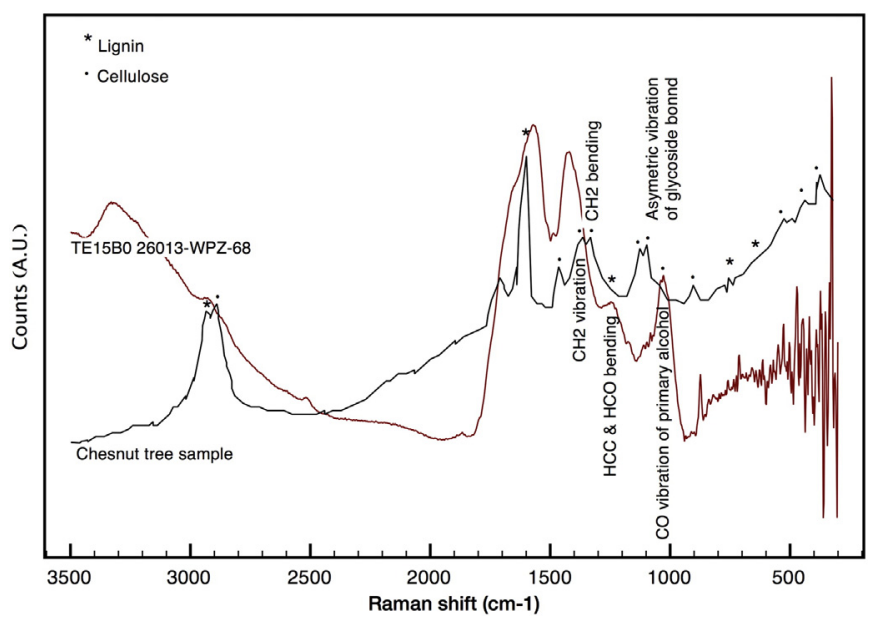

Fig. 11. sample TE15B0 26013-WPZ-68 Raman spectra compared to chestnut typical spectra (Marengo et al., 2003) and band asigment (after Atalla et al., 1987; Kavler and Demsar, 2012; Marengo et al., 2003).

the 2nd millennium cal. BC in Carapinhais and Castro dos Ratinhos, passing through the end of the 4th millennium cal. BC in Cerro Ortega, and second half of the 3rd millennium cal. BC in Valencina de la Concepción, Valle de las Higueras, Las Cabezas II and La Sima. Therefore, based on the available data there is no clear pattern of use. What does seem certain, bearing in mind the sheer volume of beads, is that more clinochlore would have been used during the second half of the 3rd millennium cal BC. This conclusion can be drawn considering that Dinamarca Street, Las Cabezas II and La Sima contained a total of 175 beads compared with 2 from Cerro Ortega (Late Neolithic), 17 from Carapinhais (Early Bronze Age) and the single bead of Castro dos
Ratinhos (Late Bronze Age). Two clinochlore beads were recorded at Cova da Moura, dating back to between the 5th millennium cal BC and the start of the 3rd millennium cal BC.

\section{Conclusion}

Our analysis of beads and pendants from Castillejo del Bonete (Terrinches, Ciudad Real) and Cerro Ortega (Villanueva de la Fuente, Ciudad Real) enable us to make a contribution to the La Mancha region map of green bead body ornament pieces. The material from El Castillejo del Bonete shows that these objects were used at the very least during the late Copper Age/early Bronze Age (2465-2211 cal. BC). Thus, the outdated concern for delimiting green ornament distribution areas is discarded and a new argument for a wide circulation across practically the entirety of the Iberian Peninsula arises. The studied beads fit into a general trend towards a diversification of colour, shape and raw material related with the emergence of farming and village life that lasts from 6th/5th millennia cal. BC to the end of the 4th millennium cal. BC, when green stones and particularly variscite began to dominate the archaeological record (during 3rd millennium cal. BC and peaking at 27002300 cal. BC (Villalobos García \& Odriozola, 2016)). Parallel to variscite apogee, a process of growing social inequality and hierarchisation started (Chapman, 2008, 2003; Gilman, 1981) that ended in the 2nd millennium cal. BC with the consolidation of hierarchised societies, complex socio-political structures and 'social stratification' (Garcia Sanjuán, 2006). It was then when variscite was substituted by green micas and new signifying objects made out of gold or silver (Odriozola et al., 2015).

New questions arise as to how this green ornament usage system functioned, what exchange networks involved exactly and what the relationship was between these circumstances and symbolic, ethnic and systems of social representation.

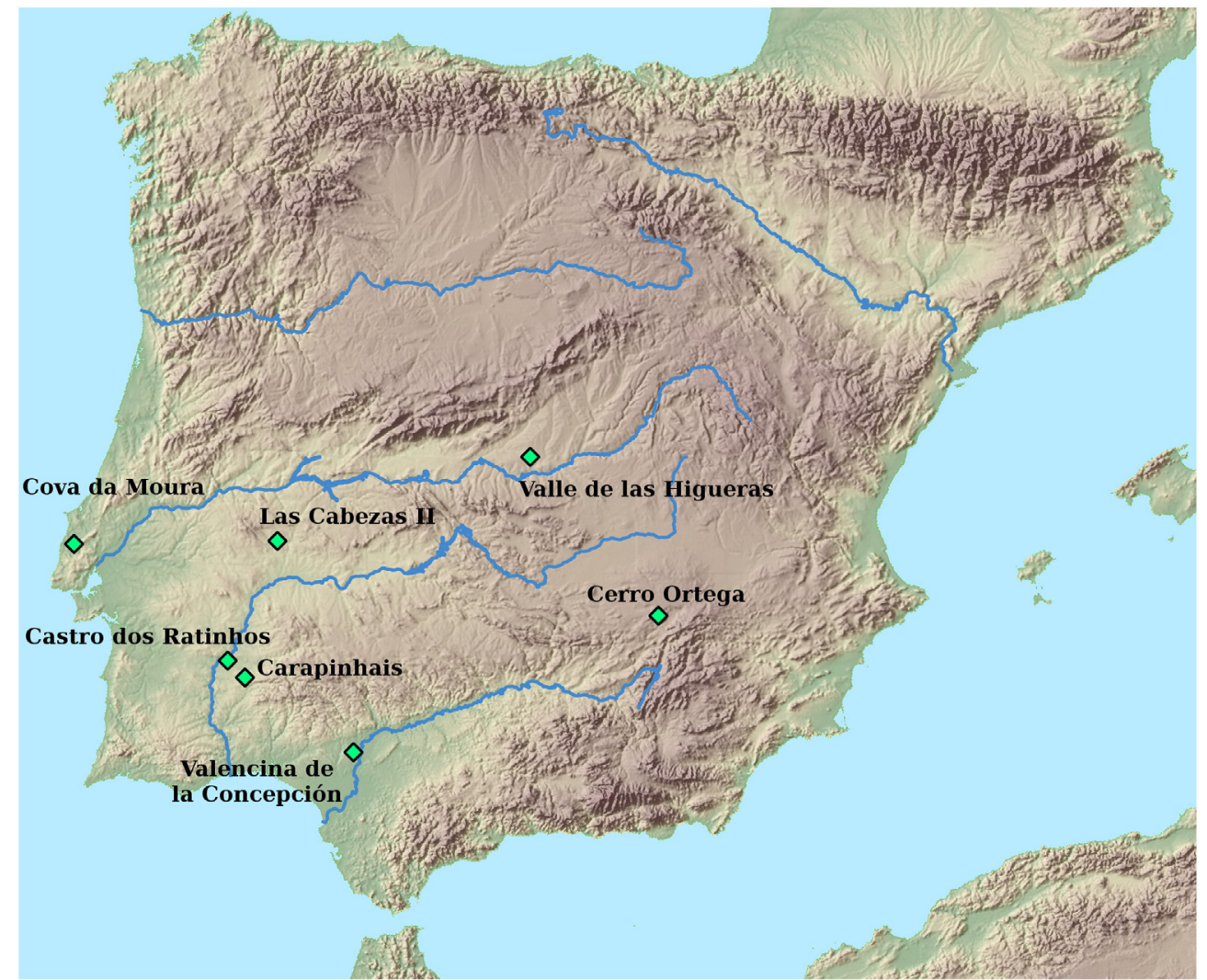

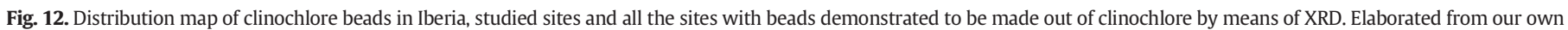
database (R + D project HAR2012-34620) and published data (Dominguez Bella, 2010; Gonçalves et al., 2011; Huet Gonçalves, 2007). 
The mineralogical and composition analyses conducted on the beads of El Castillejo del Bonete suggest that there was an as-yet-unknown variscite outcrop. By way of a hypothesis, we propose that it could have supplied the south-eastern region of the peninsula with the raw material for the green ornaments made from this material.

Also, in this study we provide the identification of clinochlore beads at Cerro Ortega. So far, only half a dozen prehistoric sites with clinochlore beads have been reported. Their distribution throughout a large part of the Iberian Peninsula, widespread even with regard to natural sources of this type of material, means that neither a possible origin nor a distribution mechanism for the raw material can be suggested.

To date, we can only suggest that various minerals were used to make green body ornaments on the Iberian Peninsula in Late Prehistory, and occasionally exotic materials were preferred to other similar or identical local materials. This means that there were occasions during which the pure model "down-the-line/prestige chain" (Renfrew, 1975) was not followed, which would indicate that alterations were made. What form these took (cultural, social, political exchanges, etc.) is something we shall delve into more deeply once we have further information (Benitez de Lugo et al., 2015).

\section{Acknowledgements}

Project financed by MINECO as part of the non-directed $\mathrm{R}+\mathrm{D}$ programme (HAR2012-34620).

To the University of Seville for the postdoctoral grant within VPPIUS (5th University of Seville Research Plan).

To the local councils of Villanueva de la Fuente and Terrinches, and especially their mayors Mr. Juan Ángel Amador Fresneda and Mr. Nicasio Peláez Peláez, who made studying these archaeological sites possible.

To the team of MOROTE TRADUCCIONES for their assistance with the translation.

\section{References}

Alqap, A.S.F., Iis, S., 2009. Low temperature hydrothermal synthesis of calcium phosphate ceramics: effect of excess Ca precursor on phase behavior. Indian J. Chem. A 48, 1492-1500.

Atilla, R.H., American Chemical Society, American Chemical Society (Eds.), 1987. The Structures of Cellulose: Characterization of the Solid State. ACS Symposium Series 340ACS Symposium Series 340. American Chemical Society, Washington, DC.

Baldellou, V., Utrilla Miranda, P., García-Gazólaz, J., 2012. Variscita de Can Tintorer en el Neolítico Antiguo del Valle Medio del Ebro. In: Borrell, M., Borrell, F., Bosch, J., Clop, X., Molist, M. (Eds.), Actes Xarxes al Neolític. Rubricatum. Museu de Gavà, Gavà (Barcelona), pp. 307-314.

Barrio Aldea, C., Maquedano Carrasco, B., 2000. La necrópolis calcolítica de Cerro Ortega (Villanueva de la Fuente), in: El Patrimonio Arqueológico de Ciudad Real: Métodos de Trabajo Y Actuaciones Recientes. Centro Asociado de Valdepeñas-Ciudad Real. pp. 67-86.

Benítez de Lugo Enrich, L., Álvarez García, H.J., Fernández Martín, S., Mata Trujillo, E. Moraleda Sierra, J., Palomares Zumajo, N., Odriozola Lloret, C., Morgado Rodríguez, A., Salazar García, D.C., 2014. Castillejo del Bonete (Terrinches, Ciudad Real): un complejo tumular prehistórico de la Cultura de las Motillas en el Alto Guadalquivir. Menga 2014 Num 5, 151-173.

Benítez de Lugo Enrich, L., Palomares Zumajo, N., Álvarez García, H.J., Barroso Bermejo, R., Benito Sánchez, M., Blain, Hugues-Alexandra, Bueno Ramírez, P., De Balbín Behrmann, Fernández Martín, S., López-Sáez, J.A., Galindo Pellicena, M.A., Garrido Martínez, M.A., Laplana Conesa, C., Mata Trujillo, E., Menchén Herreros, G., Montero Ruiz, I., Moraleda Sierra, J., Morgado Rodríguez, A., Odriozola Lloret, C., Polo Martín, E., Ruiz-Alonso, M., Sevilla García, P., Schuhmacher, T.X., Salazar-García, D.C., 2015. Paleoecología y cultura material en el complejo tumular prehistórico de Castillejo del Bonete (Terrinches, Ciudad Real)". Menga, Revista de Prehistoria de Andalucía, 2015 Num 6, 112-140.

Benítez de Lugo, L., Álvarez, H.J., Garrido, M.A., Sánchez, J.L., Hermana, F., Molina, M., Moraleda, J., 2008. El calcolítico en el alto Guadiana. Artesanos de cuentas en el interior peninsular: Los Parrales (Arenas de San Juan, Ciudad Real). Espac. Tiempo Forma Ser. Prehist. Arqueol. 189-211.

Borrell, F., Bosch, J., Vicente, O., 2009. Datacions per radiocarboni a les mines neolítiques de La Serra de Les Ferreres de Gavà. Rubricatum 4, 241-246.

Chapman, R., 2003. Archaeologies of Complexity. Routledge, London.

Chapman, R., 2008. Producing inequalities: regional sequences in later prehistoric Southern Spain. Journal of World Prehistory 21, 195-260.
Campano Lorenzo, A., Rodríguez Marcos, J.A., Sanz Mínguez, C., 1985. Apuntes para una primera valoración de la explotación y comercio de la variscita en la Meseta Norte. Anu. Inst. Estud. Zamor. Florián Ocampo 1985, 13-22.

Camprubi, A., Costa, F., Melgarejo, J.C., 1994. Mineralizaciones de fosfátos férricosalumínicos de GAVÀ (Catalunya): tipología. Bol. Geol. Min. 105, 444-453.

Dominguez Bella, S., 2012. Archaeomineralogy of prehistoric artifacts and gemstones. In: Herrero, J.M., Vendrell-Saz, M. (Eds.), Archaeometry and Cultural Heritage: The Contribution of Mineralogy. Seminarios de La Sociedad Española de Mineralogía. Sociedad Española de Mineralogía. Museo Geominero del Instituto Geológico y Minero de España, España, pp. 5-28.

Dominguez Bella, S., 2010. Objetos ornamentales en el Calcolítico del centro de la Península Ibérica. Estudio analítico de las cuentas de collar de los enterramientos prehistóricos del Valle de las higueras (Toledo). In: Dominguez Bella, S., Ramos Muñoz, J., Pérez Rodríguez, M. (Eds.), Minerales Y Rocas En Las Sociedades de La Prehistoria. Universidad de Cádiz, Cádiz, pp. 275-284.

Edo, M., Blasco, A., Villalba, M.J., Gimeno, D., Fernández Turiel, J.L., Plana, F., 1995. La caracterización de la variscita del complejo minero de Can Tintorer, una experiencia aplicada al conocimiento del sistema de bienes de prestigio durante el neolítico. In: Bernabeu, J., Orozco Köhler, T., Terradas, X. (Eds.), Los Recursos Abióticos En La Prehistoria. Aprovisionamiento E Intercambio. Universitat de Valencia Caracterización, pp. 83-110.

Edwards, H.G.M., Chalmers, J.M., 2005. Raman Spectroscopy in Archaeology and Art History. Springer Verlag.

Fábregas Valcarce, R., 1991. Megalitismo del Noroeste de la Península Ibérica. Tipología y secuencia de los materiales Líticos. Aula Abierta. Universidad Nacional de Educación a Distancia, Madrid.

Fernández Turiel, J.L., Gimeno, D., Plana, F., Blasco, A., Edo, M., Villalba Gordo, J., 1990 Estudio de las mineralizaciones fofáticas del complejo minero neolítico de Can Tintorer (Gavá, Barcelona) y comparación con las cuentas procedentes de ajuares arqueológicos. Bol. Soc. Esp. Mineral. 13, 86-87.

Galán Saulnier, C., Sánchez Meseguer, J., 1994. Santa María del Retamar. 1984-1994. Arqueología En Ciudad Real. Junta de Comunidades de Castilla-La Mancha, Toledo, pp. 87-110.

Garcia Sanjuán, L., 2006. Funerary ideology and social inequality in the Late Prehistory of the Iberian South-West (c. 3300-850 cal. BC). In: Díaz del Rio, P., Garcia Sanjuan, L. (Eds.), Social Inequality in Iberian Late Prehistory, International Series. Archaeopres, Oxford, pp. 149-169.

Gilman, A., 1981. The development of social stratification in bronze age Europe. Curr Anthropol. 22, 1-23.

Gil Pitarch, P., Miquel Feucht, M.J., Negre Muñoz, M.C.d., Polo Cerdá, M., Villalaín Blanco, J.D., 1999. Estudio antropológico y paleopatológico de los restos óseos del yacimiento neolítico de Villanueva de la Fuente (Ciudad Real). SAGVNTVM Extra 2, 387-391.

Gonçalves, A.P., Soares, A.M.M., Silva, A.C., Berrocal-Rangel, L., 2011. Stone beads from late bronze age and early iron age settlements from South-Western Portugal: analyses by X-ray diffraction. In: Turbanti-Memmi, I. (Ed.), Proceedings of the 37th International Symposium on Archaeometry, 13th-16th May 2008, Siena, Italy. Springer, Berlin Heidelberg, pp. 227-231.

Guitián Rivera, F., Vázquez Varela, J.M., 1975. Análisis radiográfico de cuentas de calaíta gallegas. Bol. Com. Monum. Históricos Artísticos Lugo 9, 187-188.

Herbaut, F., Querré, G., 2004. La parure néolithique en variscite dans le sud de l'Armorique. Bull. Société Préhistorique Fr. 101, 497-520. http://dx.doi.org/10.3406/ bspf.2004.13029.

Huet Gonçalves, A.A., 2007. Identificação mineralógica de uma conta da Necrópole dos Carapinhais (Sobral da Adiça, Moura). VIPASCA 2, 191-193.

Kavler, K., Demsar, A., 2012. Application of FTIR and Raman spectroscopy to qualitative analysis of structural changes in cellulosic fibres. Tekstilec 55 (1), 19-31.

Larsen, E.S., 1942a. The mineralogy and paragenesis of the variscite nodules from Near Fairfield, Utah part 1. Am. Mineral. 27, 281-300.

Larsen, E.S., 1942b. The mineralogy and paragenesis of the variscite nodules from Near Fairfield, Utah part 2. Am. Mineral. 27, 350-372.

Larsen, E.S., 1942c. The mineralogy and paragenesis of the variscite nodules from Near Fairfield, Utah part 3. Am. Mineral. 27, 441-451.

Marengo, E., Robotti, E., Liparota, M.C., Gennaro, M.C., 2003. A method for monitoring the surface conservation of wooden objects by Raman spectroscopy and multivariate control charts. Anal. Chem. 75 (20), 5567-5574. http://dx.doi.org/10.1021/ac0300791.

Marini, C., Gimeno, D., Sistu, G., 1989. Le mineralizzazioni a variscite del Sarrabus. Bol Soc Geol It 108, 357-367.

Massé, R., 1971. Découvert de minyulite, wavellite et variscite dans les phtanites de Pannecé. Bull. Société Sci. Nat. Ouest Fr. LXIX 12-15.

Montero Ruiz, I., Benítez de Lugo Enrich, L., áLvarez GarcíA, H.J., GutiéRrez-Neira, P.C. Murillo-Barroso, M., Palomares Zumajo, N., MenchéN Herreros, G., Moraleda Sierra, J., Salazar-GarcíA, D., 2014. Cobre para los muertos. Estudio arqueométrico del material metálico procedente del monumento megalítico prehistórico de Castillejo del Bonete (Terrinches, Ciudad Real). Zephyrvs 73 (109). http://dx.doi.org/10.14201/ zephyrus201473109132.

Moro, M.C., Gil-Agero, M., Cembranos Pérez, M.L., Pérez del Villar, L., Fernández Fernández, A., 1995. Las mineralizaciones estratiformes de variscita (Aluminofosfatitas) silúricas de los Sinformes de Alcañices (Zamora) y Terena (Huelva) (España). Bol. Geol. Min. 106, 233-249.

Muñoz Amilibia, A.M., 1965. La Cultura neolítica catalana de los "Sepulcros de fosa," Publicaciones Eventuales. Universidad de Barcelona, Barcelona.

Nieto Gallo, G., Sánchez Meseguer, J., 1980. El Cerro de la Encantada. Granátula de Calatrava (Ciudad Real). Ministerio de Cultura, Madrid.

Odriozola, C.P., 2014. A new approach to determine the geological provenance of variscite artifacts using the $\mathrm{P} / \mathrm{Al}$ atomic ratios. Archaeol. Anthropol. Sci. http://dx.doi.org/10. 1007/s12520-014-0195-2. 
Odriozola, C.P., García Sanjuán, L., 2013. Las cuentas de collar de piedra verde de Matarrubilla (Valencina de la Concepción, Sevilla). In: García Sanjuán, L., Vargas Jiménez, J.M., Hurtado Pérez, V., Ruiz Moreno, T., Cruz-Auñón Briones, R. (Eds.), El Asentamiento prehistórico de Valencina de la Concepción (Sevilla): investigación y Tutela en el 150 Aniversario del Descubrimiento de La Pastora. Historia y Geografía. Universidad de Sevilla, Sevilla, pp. 485-494.

Odriozola, C.P., Linares Catela, J.A., Hurtado Pérez, V., 2010a. Variscite source and source analysis: testing assumptions at Pico Centeno (Encinasola, Spain). J. Archaeol. Sci. 37, 3146-3157. http://dx.doi.org/10.1016/j.jas.2010.07.016.

Odriozola, C.P., Linares Catela, J.A., Hurtado, V., 2010b. Variscite source and source analysis: testing assumptions at Pico Centeno (Encinasola, Spain). J. Archaeol. Sci. 37, 3146-3157.

Odriozola, C.P., Villalobos García, R., 2015. La explotación de variscita en el Sinforme de Terena: el Complejo minero de Pico Centeno (Encinasola, Huelva). Trab. Prehist. 72 (2), 335-345.

Odriozola, C.P., Villalobos-García, R., Burbidge, C.I., Boaventura, B., Sousa, A.C., RodríguezAriza, O., Parrilla-Giraldez, R., Prudênçio, M.I., Dias, M.I., 2015. Iberian Variscite mining and consumption: distribution and chronological framework from Pico Centeno (Encinasola, Spain). Quat. Res. (acepted).

Poyato, C., Espadas, J., 1994. El Cerro de El Castellón (Villanueva de los Infantes, Ciudad Real): la cabecera del Jabalón durante el III Milenio. Arqueología En Ciudad Real. Junta de Comunidades de Castilla-La Mancha, Toledo, pp. 41-68.

Pozo, M., Casas, J., Medina, J.A., 2002. Estudio mineralógico de componentes ornamentales pétreos procedentes de un yacimiento de la Cultura del Argar (Fuente Álamo, Almería). Bol. Geol. Min. 113, 131-142.
Renfrew, C., 1975. Trade as Action at a Distance: Questions of Integration and Communication. In: Sabloff, J.A., Lamberg-Karlovsky, C.C. (Eds.), Ancient Civilization and Trade. School of American Research Advanced Seminar Series. University of New Mexico Press, Albuquerque, pp. 3-59.

Ríos Mendoza, P., Liesau von Lettow-Vorbeck, C., 2011. Elementos de adorno, simbólicos y colorantes en contextos funerarios y singulares. In: Blasco Bosqued, M.C., Liesau von Lettow-Vorbeck, C., Ríos Mendoza, P. (Eds.), Yacimientos Calcolíticos con Campaniforme de la Región de Madrid: Nuevos Estudios, Patrimonio Arqueológico de Madrid. Universidad Autónoma de Madrid, Madrid, pp. 357-370.

Salvador, P., Fayos, J., 1972. Some aspects of the structural relationship between "meshbach-type" and lucin-type" variscites. Am. Mineral. 57, 36-44.

Smith, G.D., Clark, R.J.H., 2004. Raman microscopy in archaeological science. J. Archaeol. Sci. 31, 1137-1160. http://dx.doi.org/10.1016/j.jas.2004.02.008.

Taffinder, J., 1998. The Allure of the Exotic: The Social Use of Non-local Raw Materials During the Stone Age in Sweden.

Vázquez Varela, J.M., 1975. Cuentas de "calaita” en la Península Ibérica: datos para la revisión del problema. Gallaecia 25-30.

Villalobos García, R., Odriozola, C.P., 2016. First approach to the organisation of variscite body ornament production during Late Prehistory in the Iberian Peninsula: the mines of Aliste and production loci of Quiruelas de Vidriales (Zamora, Spain). Eur. J. Archaeol. http://dx.doi.org/10.1080/14619571.2016.1147316 (accepted).

Willing, M., Stöcklmayer, S., Wells, S., 2008. Ornamental variscite: a new gemstone resource from Western Australia. J. Gemmol. 31, 111-124. 